\title{
Lacidipine Attenuates Apoptosis via a Caspase-3 Dependent Pathway in Human Kidney Cells
}

\author{
Aiqi Zhang ${ }^{\mathrm{a}}$ Shuli Fu Lan Chen $^{\mathrm{a}}$ Lihong Ren ${ }^{\mathrm{a}}$ Shuqiang Qu Yujing Zhang ${ }^{\mathrm{a}}$ \\ Li Yao ${ }^{a}$ Shufen Yang ${ }^{a}$ \\ ${ }^{a}$ Department of Pediatrics, the Second Affiliated Hospital of Harbin Medical University, Harbin, China
}

\section{Key Words}

Lacidipine $\cdot$ Apoptosis $•$ ATP depletion and recovery $•$ Human kidney cells

\begin{abstract}
Background: Acute kidney injury (AKI) is common in hospitalised patients and has a poor prognosis. Therefore, new therapeutic strategies are anticipated. Lacidipine, a novel thirdgeneration dihydropyridine calcium channel blocker, has been demonstrated effective for hypertension. However, its potential effect on renal injury remains unknown. In the present study, an in vitro model of renal ischemia reperfusion (I/R) injury was used to investigate the protective effect and underlying mechanisms of lacidipine on human kidney cell (HKC) apoptosis. Methods: HKCs were subjected to adenosine triphosphate (ATP) depletion and recovery $(0.01 \mu \mathrm{M} \mathrm{AA}$, depletion for $2 \mathrm{~h}$ and recovery for $30 \mathrm{~min})$, with or without lacidipine $(1 \mu \mathrm{M}$ and $10 \mu \mathrm{M}, 24 \mathrm{~h})$, then cell viability and apoptosis were determined using the cell counting kit-8 (CCK-8) assay and Annexin $\mathrm{V}$ flow cytometry. The expression of $\mathrm{BCl}-2$, Bax, and cytochrome $c$ (cyt $c$ ) was examined by western blot. Results: Antimycin A (AA) was found to induce apoptosis of HKCs. The proportion of early apoptosis and activity of caspase-3 peaked at 30 min after ATP depletion and recovery and were attenuated by lacidipine. The expression of cyt $\mathrm{c}$ and Bax was decreased, while that of $\mathrm{Bcl}-2$ was increased significantly in lacidipine treated group. Conclusion: We conclude that lacidipine protects HKCs against apoptosis induced by ATP depletion and recovery by regulating the caspase- 3 pathway.
\end{abstract}




\section{Cellular Physiology Cell Physiol Biochem 2013;32:1040-1049 \begin{tabular}{l|l} 
and Biochemistry Published online: October 04, 2013 & $\begin{array}{l}\text { C) 2013 S. Karger AG, Basel } \\
\text { www.karger.com/cpb }\end{array}$ \\
\hline
\end{tabular} \\ Zhang et al.: Lacidipine Protects Against Renal Injury}

\section{Introduction}

Acute kidney injury (AKI) is characterised by a rapid reduction in kidney function resulting in a failure to maintain fluid, electrolyte and acid-base homoeostasis in clinical practice. Recently, AKI has been paid more attention because of its high morbidity and mortality [1]. The incidence of AKI in adults and children has been increasing over the past decades. Ischemic hypoxic renal injury is the leading cause of AKI [2], and renal ischemia/ reperfusion (I/R) injury is one of the main causes of ischemic AKI. In children with complex systemic disease who survive AKI episodes, the high risk for chronic kidney disease is quite evident [3]. Cellular hypoxic damage, mainly induced by renal I/R, occurs in human kidney cells (HKCs), with necrosis and apoptosis of HKCs being the underlying pathophysiological mechanisms. Therefore, apoptosis of HKCs is an important outcome of renal I/R $[4,5]$.

The principal of treatment of AKI are to remove its causes and maintain homoeostasis. Results from double-blind, randomized controlled studies have shown that the nephroprotective effects of low-dose dopamine and loop diuretics were ineffective in reducing the incidence of AKI [6, 7]. Besides, no specific drug-based intervention has proved to be protective after hemodynamic redevelopment and removal of nephrotoxins [8]. Thus, to our knowledge, there is no established pharmacotherapeutic procedure for AKI.

Lacidipine is a novel third-generation dihydropyridine calcium channel blocker that could effectively lower blood pressure and reduce damage to the heart, brain and kidneys [9-11]. However, the effect of lacidipine on AKI is unknown, and the molecular mechanism of lacidipine in conferring protection against kidney damage is unclear. It has been suggested that lacidipine exerts an antioxidant effect and could protect endothelial cells from freeradical injury [12]. Therefore, we hypothesize that lacidipine exerts therapeutic effects against I/R through an anti-apoptotic mechanism.

In this study, we confirmed that adenosine triphosphate (ATP) depletion and recovery induce HKC apoptosis, using an in vitro model mimicking the cell injury caused by I/R. We also investigated whether lacidipine can protect HKCs from apoptosis under conditions of ATP depletion and recovery and determined the underlying mechanism.

\section{Materials and Methods}

\section{Reagents and antibodies}

Antimycin A (AA) was purchased from Sigma (St. Louis, MO, USA) and dissolved in phosphatebuffered saline (PBS). Lacidipine was provided by Sanchine (Harbin, China), which was dissolved in dimethylsulphoxide (DMSO). The final concentration of DMSO did not exceed $0.1 \%$. Cell counting kit-8 (CCK8) , bicinchoninic acid (BCA) detection kit and anti-caspase-3 antibodies were purchased from Beyotime (Jiangsu, China). Polyvinylidene difluoride (PVDF) membranes were purchased from Millipore (Billerica, MA, USA). Enhanced chemiluminescence (ECL) kit was provided by Thermo Fisher Scientific (Rockford, IL, USA). Rabbit anti-Bax, Bcl-2 and cyt- $c$ antibodies were purchased from Cell Signaling Technology (Danvers, MA, USA). Mouse anti- $\beta$-Actin antibody was purchased from Beijing Zhongshan Biotech Co. (Beijing, China). Goat anti-rabbit IgG and goat anti-mouse IgG were purchased from Rockland (Gilbertsville, PA, USA). Annexin V-FITC and propidium iodide (Annexin V-FITC/PI) was provided by Biosea Corporation (Beijing, China).

\section{Cell culture}

HKCs were obtained from Cell Resource Center, IBMS, CAMS/PUMC (CRC/PUMC, China) and grown in Dulbecco's Modified Eagle's medium/F12 (DMEM/F12, Gibco, Grand Island, NY,USA) supplemented with $10 \%$ fetal bovine serum (FBS; Gibco, Grand Island, NY,USA) at $37^{\circ} \mathrm{C}$ with $5 \% \mathrm{CO}_{2}$ in a humidified atmosphere. The cells used in these experiments were in their logarithmic phase of growth. The in vitro model of HKC apoptosis was established using AA. After designated doses of AA were added in the medium, the cells were incubated for $2 \mathrm{~h}$, after which the culture medium was changed to the regular medium. The cells had been 


\section{Cellular Physiology Cell Physiol Biochem 2013;32:1040-1049 \begin{tabular}{l|l|l} 
DOI: 10.1159/000354504 04,2013 & O 2013 S. Karger AG, Basel
\end{tabular} \\ Zhang et al.: Lacidipine Protects Against Renal Injury}

pre-incubated with designated concentrations of lacidipine for $24 \mathrm{~h}$ before the model of apoptosis was established.

\section{Cell proliferation assay}

HKCs were seeded in 96-well plates at a density of 7500 cells per well with $200 \mu$ l of complete culture medium. They were incubated in DMEM/F12 with 10\% FBS for $24 \mathrm{~h}$. After equal durations of treatment with $\mathrm{AA}$ (final concentration, $0.0001 \mu \mathrm{M}$ to $10 \mu \mathrm{M}$ ) and lacidipine (final concentration, $0.01 \mu \mathrm{M}$ to 100 $\mu \mathrm{M}$ ), the cells were trypsinized and their viability determined using CCK-8.After chemical stimulation, the supernatant was removed, and $200 \mu \mathrm{L}$ of DMEM/F12 medium containing $20 \mu \mathrm{L}$ CCK-8 was added to each well, followed by further incubation for $3 \mathrm{~h}$ at $37^{\circ} \mathrm{C}$. The culture plates were shaken for $10 \mathrm{~min}$, and the optical density (OD) values were read at $450 \mathrm{~nm}$. For each sample, six parallel experimental groups were used to assess cell viability.

\section{Flow cytometric analysis}

For this analysis, $10^{6}$ cells were incubated with $0.01 \mu \mathrm{M}$ AA. The culture medium was then changed to the regular medium at different times. Two concentrations of lacidipine were added to the HKC $24 \mathrm{~h}$ before the model of apoptosis established. The prepared cells were washed twice with cold PBS and resuspended in $500 \mu$ l of binding buffer (10 mM HEPES/NaOH [pH 7.4], $140 \mathrm{mM} \mathrm{NaCl}, 2.5 \mathrm{mM} \mathrm{CaCl}_{2}$ ) at a concentration of $1 \times 10^{6}$ cells $/ \mathrm{ml}$. Then, $5 \mu \mathrm{l}$ of AnnexinV-FITC and $10 \mu \mathrm{l}$ of $20 \mu \mathrm{g} / \mathrm{ml}$ PI were added to the cells, which were analyzed with a flow cytometer (Beckman, S. Kraemer Boulevard Brea, CA, USA). Viable cells were negative for both PI and Annexin V; apoptotic cells were positive for Annexin V and negative for PI, and lateapoptotic dead cells showed both Annexin V and PI positivity. Non-viable cells, which underwent necrosis, were positive for PI and negative for Annexin V.

Assay of caspase-3 activity

Caspase-3 activity was measured using the caspase-3 assay kit according to the manufacturer's protocol. After treatment with AA and lacidipine, the cells were lysed with $50 \mu \mathrm{l}$ of chilled cell lysis buffer, and $50 \mu \mathrm{l}$ of $2 \times$ reaction buffer and $5 \mu \mathrm{l}$ of the appropriate conjugated substrate at a concentration of $1 \mathrm{mM}$ were added to each lysate. The mixture was incubated in a water bath at $37^{\circ} \mathrm{C}$ for $1 \mathrm{~h}$, and the absorbance was measured using a microtiter plate reader at a test wavelength of $405 \mathrm{~nm}$.

\section{Western blot analysis}

HKCs treated with lacidipine ( $1 \mu \mathrm{M}$ or $10 \mu \mathrm{M}$ for $24 \mathrm{~h})$ and $\mathrm{AA}(0.01 \mu \mathrm{M}$ for $2 \mathrm{~h}$, with 30 min recovery) were suspended in lysate buffer. Protein concentrations were assayed with the BCA detection kit, and samples were resolved by sodium dodecyl sulphate polyacrylamide gel electrophoresis (SDS-PAGE). These samples were transferred into PVDF membranes. Then, membranes were blocked with Tris buffered saline (TBS) with $0.05 \%$ Tween-20 containing $5 \%$ nonfat dry milk for $1 \mathrm{~h}$ and then incubated at $4^{\circ} \mathrm{C}$ overnight with appropriate primary antibodies ( $\beta$-actin,1:800; Bax,1:1000; Bcl-2,1:300; cyt-c,1:300). Membranes were washed with TBST, incubated with appropriate secondary antibodies (1:4000) for $1 \mathrm{~h}$. Signal strength was measured using an ECL kit and the relative photographic density quantified using an Odyssey Fc Imaging System. Protein levels were normalized to $\beta$-actin.

\section{Statistical Analysis}

The results are presented as the means \pm standard deviation (SD). The data were analyzed by one-way ANOVA using SPSS17.0. The Student t-test was used to analyse the differences between the groups, which were considered statistically significant at $\mathrm{p}<0.05$.

\section{Results}

Effect of $A A$ on the viability of HKCS

In order to assess the cytotoxic effect of AA on HKCs, the cells were cultured with AA at final concentrations ranging from $0.0001 \mu \mathrm{M}$ to $10 \mu \mathrm{M}$ for $2 \mathrm{~h}$, then CCK-8 assays were tested. 


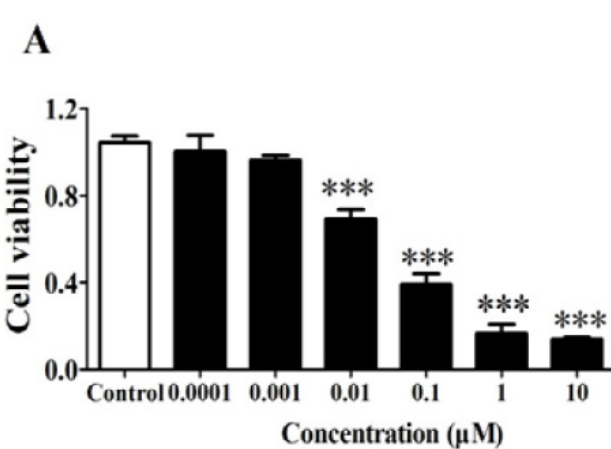

C

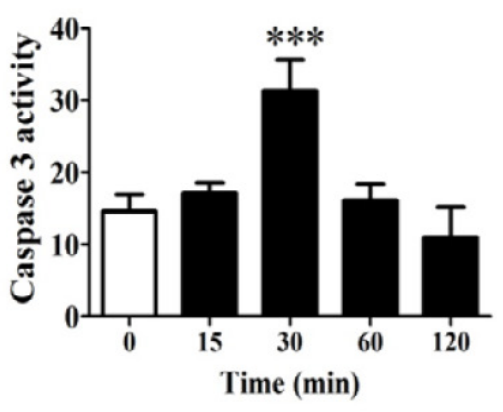

\section{B}

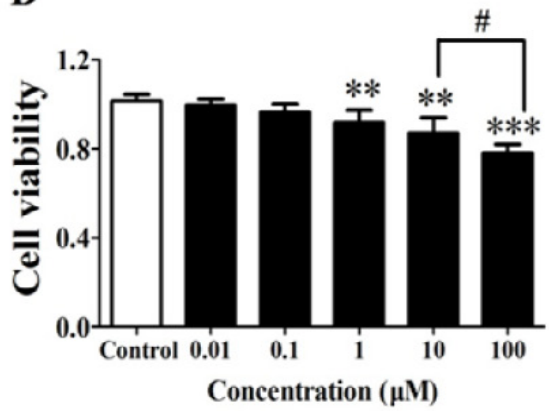

D

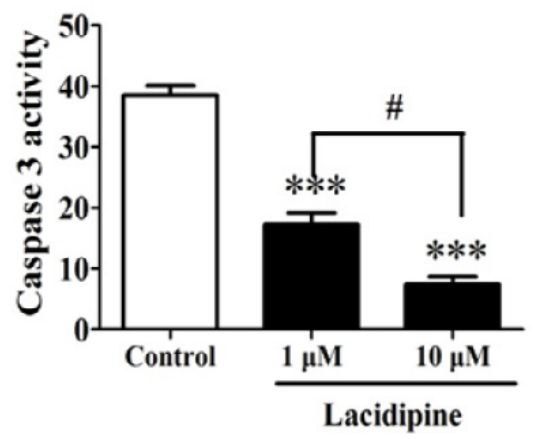

Fig. 1. Effects of lacidipine, antimycin A (AA) and ATP depletion and recovery on the viability of human kidney cells (HKCs) and caspase-3 activity. (A): Effect of AA on the viability of HKCs. The cells were treated with ATP depletion buffer (control, containing $0.0001 \mu \mathrm{M}$ to $10 \mu \mathrm{M} \mathrm{AA}$ ) for $2 \mathrm{~h}$. Values are means \pm SD; $\mathrm{n}=6$. ${ }^{* * *}$ vs control, $\mathrm{p}<0.001$. Y-axes mean optical density (OD) values. (B): Effect of lacidipine on the viability of HKCs. The cells were treated with lacidipine buffer (control, containing $0.01 \mu \mathrm{M}$ to $100 \mu \mathrm{M}$ lacidipine) for $24 \mathrm{~h}$. Values are means $\pm \mathrm{SD} ; \mathrm{n}=6$. ${ }^{* * *}$ vs control, $\mathrm{p}<0.001$. Y-axes mean OD values. (C): Effect of ATP depletion and recovery on Caspase-3 activity in HKCs. The cells were treated with ATP depletion (AA 0.01 $\mu \mathrm{M}$ for $2 \mathrm{~h}$ ) and recovery for 0 (A), 15 (B), 30 (C), 60 (D), 120 (E) min (recovery for $0 \mathrm{~min}$, recovery for $15 \mathrm{~min}$, recovery for $30 \mathrm{~min}$, recovery for $60 \mathrm{~min}$, recovery for $120 \mathrm{~min}$ ). The mixture was incubated in a water bath at $37^{\circ} \mathrm{C}$ for $1 \mathrm{~h}$, and the absorbance was measured by microtiter plate reader at a test wavelength of 405 $\mathrm{nm}$. The standard curve is $\mathrm{y}=415.0 \mathrm{x}-21.06, \mathrm{R}^{2}=0.999$. Values are means $\pm \mathrm{SD} ; \mathrm{n}=3$. ${ }^{* * *}$ vs control, $\mathrm{p}<0.001$. (D): Effect of lacidipine on Caspase- 3 activity in injured HKCs. The cells were treated with lacidipine $(1 \mu \mathrm{M}$, $10 \mu \mathrm{M}$ ) for $24 \mathrm{~h}$, after which apoptosis model was established. Values are means $\pm \mathrm{SD} ; \mathrm{n}=3$. ${ }^{* * *}$ vs control, $\mathrm{p}$ $<0.001$, \# VS $1 \mu \mathrm{M}, \mathrm{p}<0.05$.

Cells cultured in AA-free media were used as the control. The inhibition of HKC proliferation caused by AA was assessed. As shown in Fig. 1A, in vitro HKCs growth was inhibited by AA in a concentration-dependent manner. Significant differences were found in viability reduction from the $0.01 \mu \mathrm{M}$ AA group to $10 \mu \mathrm{M}$ AA group $(\mathrm{p}<0.05)$. In subsequent experiments, 0.01 $\mu \mathrm{M}$ AA was used.

\section{Effect of lacidipine on the viability of HKCS}

HKCs were cultured with lacidipine at final concentrations ranging from $0.01 \mu \mathrm{M}$ to 100 $\mu \mathrm{M}$ for $24 \mathrm{~h}$, and their viability was assessed. As shown in Fig. 1B, lacidipine inhibited HKCs proliferation in vitro in a concentration-dependent manner. OD values decreased gradually from $1 \mu \mathrm{M}$ to $100 \mu \mathrm{M}(\mathrm{p}<0.05)$. Therefore, $1 \mu \mathrm{M}$ and $10 \mu \mathrm{M}$ lacidipine were selected in subsequent experiments. 


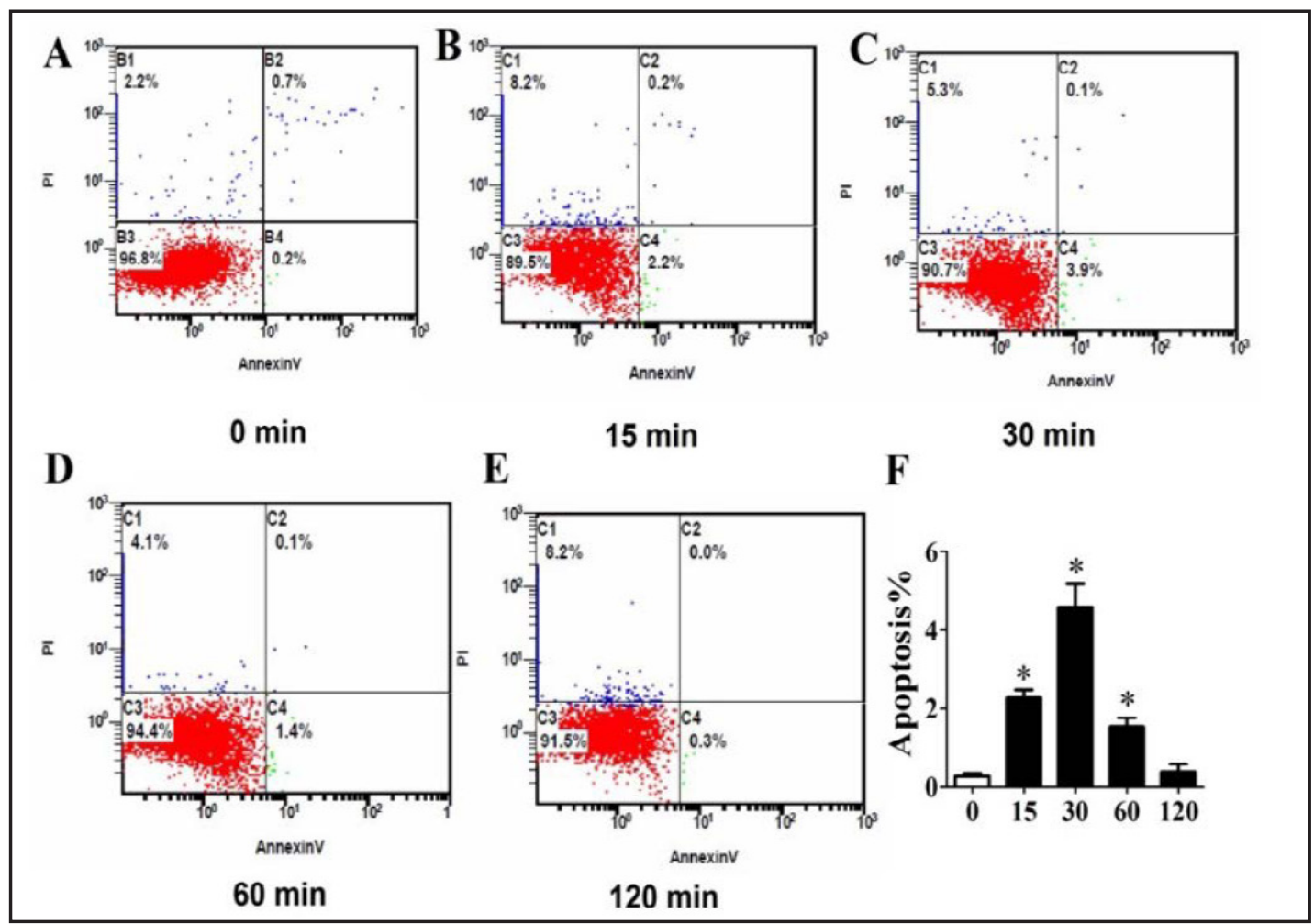

Fig. 2. Flow cytometric analysis of apoptosis rates of HKCs treated with AA (proportion of early apoptosis cells \%). The cells were treated with AA $0.01 \mu \mathrm{M}$ for $2 \mathrm{~h}$ and recovery for $0,15,30,60,120$ min (recovery for $0 \mathrm{~min}$, recovery for $15 \mathrm{~min}$, recovery for $30 \mathrm{~min}$, recovery for $60 \mathrm{~min}$, recovery for $120 \mathrm{~min}$ ). Then the cells were trypsinized and stained with Annexin V and PI. The proportion of early apoptotic cells was different. (F): the proportion of early apoptosis cells induced by ATP depletion for $2 \mathrm{~h}$ and recovery for different times. The highest rate of early apoptosis is that at the ATP depletion for $2 \mathrm{~h}$ and recovery for $30 \mathrm{~min}$. The results were presented as the means $\pm \mathrm{SD} ; \mathrm{n}=3$. ${ }^{*}$ vs control, $\mathrm{p}<0.05$.

\section{Detection of apoptosis in AA-treated HKCs}

HKCs treated with AA $(0.01 \mu \mathrm{M}, 2 \mathrm{~h})$ followed by recovery $(0,15,30,60,120 \mathrm{~min})$ showed significant changes in Annexin V/PI staining. The percentages of early apoptotic cells are $0.27 \% \pm 0.06 \%, 2.27 \% \pm 0.21 \%, 4.57 \% \pm 0.61 \%, 1.537 \% \pm 0.23 \%, 0.377 \% \pm 0.21 \%$, respectively. As shown in Fig. 2F, the 15-, 30- and 60- min groups showed an increased proportion of early apoptotic cells $(\mathrm{p}<0.05)$ compared to the control. The highest proportion of apoptosis $(4.57 \% \pm 0.61 \%)$ occurred with ATP depletion for $2 \mathrm{~h}$ and recovery for 30 -min $(\mathrm{p}<0.05)$. Consistent with this observation, the activity of caspase- 3 changed. As shown in Fig. 1C, the caspase- 3 activity of the 30 -min group was the highest $(\mathrm{p}<0.05)$. Taken together, the results indicated that the model was well established (Fig. 1C and Fig. 2), and ATP depletion for $2 \mathrm{~h}$ and recovery for $30 \mathrm{~min}$ were selected to explore the influence of lacidipine on apoptosis of HKCs.

\section{Lacidipine prevents AA-induced HKC apoptosis}

The proportion of early apoptotic cells and caspase- 3 activity were analysed after HKCs were treated with lacidipine $(1 \mu \mathrm{M}$ and $10 \mu \mathrm{M}, 24 \mathrm{~h})$ and AA $(0.01 \mu \mathrm{M}$ for $2 \mathrm{~h}$ and 30 -min recovery). As shown in Fig. 3D, compared with the control group (3.83\% \pm 0.35$)$, the lacidipine test groups showed a lower proportion of early apoptotic cells (the percentages of $1 \mu \mathrm{M}$ and $10 \mu \mathrm{M}$ groups are $1.47 \% \pm 0.35 \%$ and $0.30 \% \pm 0.10 \%, \mathrm{p}<0.05$ ). Furthermore, caspase-3 activity was significantly reduced in the lacidipine-treated cells compared with the untreated group ( $\mathrm{p}<0.05$, Fig. 1D). Additionally, the protective effect of lacidipine on damaged cells was found to be concentration dependent. 
Fig. 3. Flow cytometric analysis of AA-induced HKCs apoptosis prevented by lacidipine. The cells were treated with lacidipine $(1 \mu \mathrm{M}, 10 \mu \mathrm{M})$ for 24 $\mathrm{h}$ before apoptosis model was established. The cells were trypsinized and stained with Annexin $\mathrm{V}$ and PI. (A): ATP depletion for 2 $\mathrm{h}$ and recovery for $30 \mathrm{~min}$ without lacidipine. (B) The cells pre-treated with $1 \mu \mathrm{M}$ lacidipine for $24 \mathrm{~h}$ and ATP depletion for $2 \mathrm{~h}$ and recovery for $30 \mathrm{~min}$. (C): The cells pre-treated with $10 \mu \mathrm{M}$ lacidipine for $24 \mathrm{~h}$ and ATP depletion for $2 \mathrm{~h}$ and recovery for $30 \mathrm{~min}$. The results were presented as the means \pm $\mathrm{SD} ; \mathrm{n}=3$. ${ }^{* * *}$ vs control, $\mathrm{p}$ $<0.001$, \#vs $1 \mu \mathrm{M}, \mathrm{p}<0.05$.

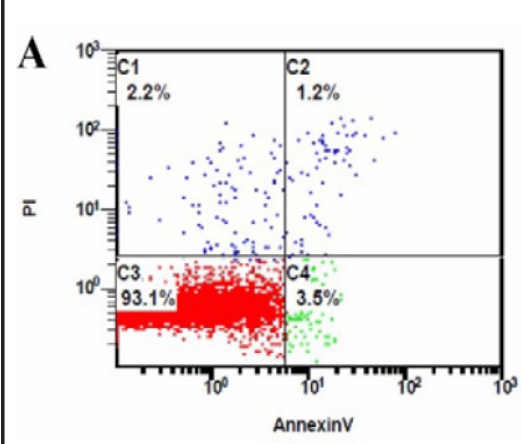

Control

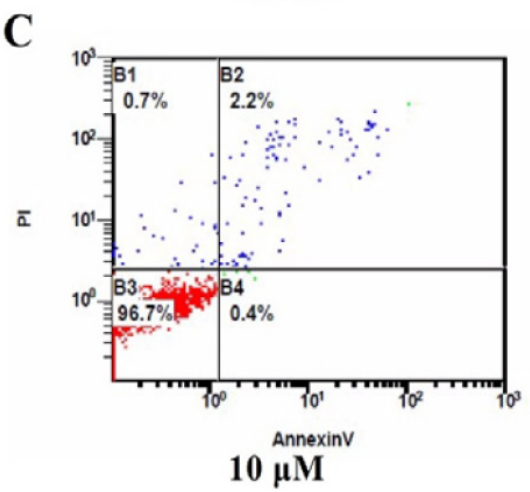

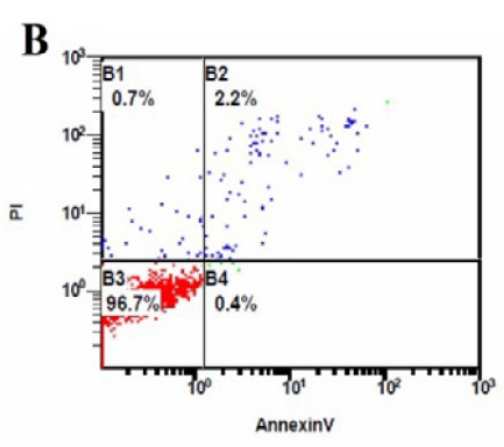

$1 \mu \mathrm{M}$

D

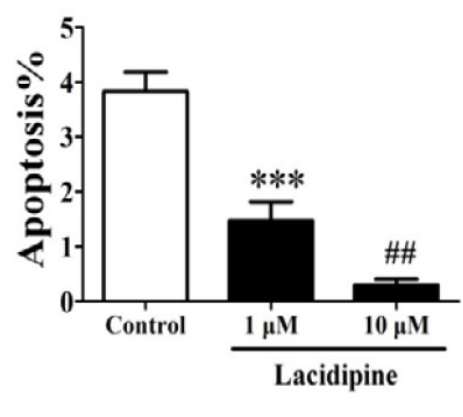

\section{Effect of lacidipine on activation of apoptotic pathways}

On the basis of the caspase-3 activity at different time-points following ATP depletion and recovery, the mitochondrial pathway of apoptosis was assessed and key factors, including cyt $c$, Bax, Bcl-2, were detected by western blot. In order to analyse the role of mitochondria and cyt $c$ dependency, the expression of cyt $c$ was analysed. Lacidipine decreased the expression of cyt $c$ of injured cells following ATP depletion and recovery (Fig. 4A, p <0.05).

In addition, we determined whether the change of cyt $c$ level was mediated by alterations in expression of the anti-apoptotic protein, $\mathrm{Bcl}-2$ and pro-apoptotic protein Bax. Significant changes were found in Bcl-2 and Bax protein levels between the injured cells group and lacidipine-treatment group. Lacidipine significantly increased the expression of the Bcl-2 protein (Fig. 4B, $\mathrm{p}<0.05$ ). In contrast, the expression of the Bax protein decreased in cells treated with lacidipine (Fig. 4C, $\mathrm{p}<0.05$ ).

\section{Discussion}

AKI is a common clinical complication characterised by an abrupt decrease in the glomerular filtration rate. Despite renal replacement therapy, the mortality associated with AKI remains high [13]. To date, no specific therapy is available to improve the clinical outcome of this condition, and therapy mostly relies on nutritional and supportive care [14, 15]. Therefore, new therapeutic strategies for patients with AKI are necessary. Interventions for inhibiting apoptosis have the potential to minimize renal dysfunction and accelerate recovery after AKI. The present study has two major findings: (1) lacidipine is effective in attenuating cell apoptosis following I/R-induced HKC injury, and (2) the protective mechanism of lacidipine is related to caspase-3 pathway.

To determine the mechanism by which lacidipine protects against HKC apoptosis, we used an in vitro cell culture model to mimick I/R. The main advantage of this model was 
A
cytochrome c
GAPDH

C

Bel2
GAPDH

$\mathbf{E}$

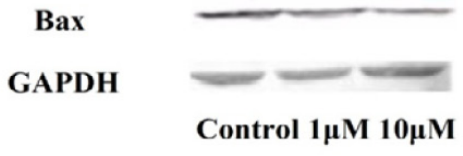

B

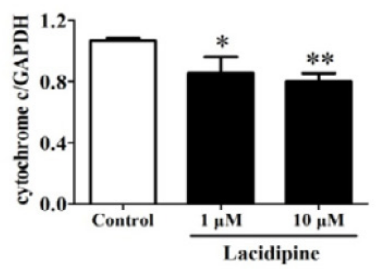

D
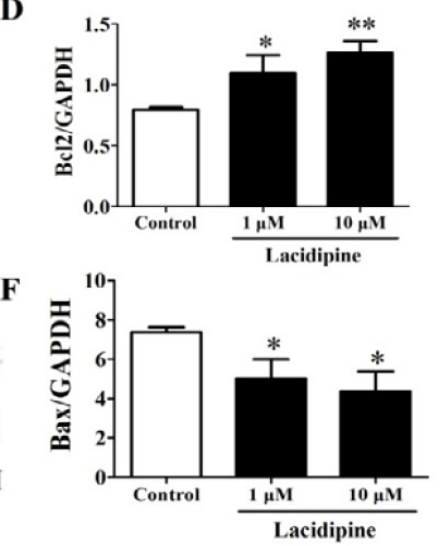

Fig. 4. Effects of lacidipine on activation of apoptotic pathways in apoptotic HKCs. The cells were pre-treated with lacidipine $(1 \mu \mathrm{M}, 10 \mu \mathrm{M})$ for $24 \mathrm{~h}$ and treated with ATP depletion for $2 \mathrm{~h}$ and recovery for $30 \mathrm{~min}$. (A, B): Cytochrome $c$ level was detected by western blot. The results showed cyt $c$ level was decreased in lacidipine treated groups. (C, D): Bcl-2 was detected by western blot. Laicidipine regulated the expression of Bcl-2 in apoptotic HKCs. The results showed that the protein level of Bcl-2 was increased in lacidipine treated groups. (E, F): Bax was detected by western blot. Laicidipine regulated the expression of Bax in apoptotic HKCs. The results showed that the protein level of Bax was decreased. Each graph represents means \pm SD; $\mathrm{n}=3$. *vs control, $\mathrm{p}<0.05,{ }^{* *}$ vs control, $\mathrm{p}<0.01$. Y-axes mean cyt $c$ relative level in HKCs, Bcl-2 relative level in HKCs, Bax relative level, respectively.

that the complexity of an in vivo model was eliminated. AA, an inhibitor of complex III of the electron-transport chain, can inhibit succinate oxidase, nicotinamide adenine dinucleotide health oxidase, and mitochondrial electron transport between cytochromes $b$ and $c$ [16]. The inhibition of electron transport causes a collapse of the proton gradient across the mitochondrial inner membrane, thereby breaking down the transmembrane potential [16, 17]. Since AA acts on mitochondria, apoptosis induced by AA has been reported in some studies $[18,19]$. While earlier studies employed different concentrations of AA [20-22], we applied a concentration of AA suited to the subsequent experiments involving CCK-8. Cells undergoing early apoptosis are usually characterized by phosphatidylserine exposure on the outer leaflet side of the plasma membrane. Based on their Annexin V-affinity, apoptotic cells can be distinguished from Annexin V-negative living cells using cytometric procedures. Further, the double labelling assay with Annexin V and PI allows a distinction between necrotic or late apoptotic (Annexin V+/PI+) and early apoptotic cells (Annexin V+/PI-). As shown in Fig. 2, pilot experiments indicated that AA can induce apoptosis of HKCs, a finding that corresponds with that of another study [4]. ATP depletion for $2 \mathrm{~h}$ and recovery for 30 min with $0.01 \mu \mathrm{M}$ AA resulted in HKC apoptosis.

It has been generally accepted that apoptosis of HKC contributes to ischemic renal dysfunction [23, 24]. This conclusion is based on reports using multiple approaches (caspase-3 activity, cyt $c$ release, Bax activation, loss of intact Bcl-2, etc.) that have shown apoptosis is a consequence of ischemia [25]. Different anti-apoptotic treatments reduce apoptosis and improve renal function after ischemia, as evidenced by studies in vivo $[26,27]$ and in vitro $[28,29] . \mathrm{Ca}^{2+}$ influx plays a crucial role in apoptosis[30]. $\mathrm{Ca}^{2+}$ overload via the reverse 


\section{Cellular Physiology Cell Physiol Biochem 2013;32:1040-1049 \begin{tabular}{l|l} 
and Biochemistry Published online: October 04, 2013 & $\begin{array}{l}\text { DO 2013 S. Karger AG, Basel } \\
\text { www.karger.com/cpb }\end{array}$ \\
\hline
\end{tabular} \\ Zhang et al.: Lacidipine Protects Against Renal Injury}

mode of $\mathrm{Na}^{+} / \mathrm{Ca}^{2+}$ exchange plays an important role in the pathogenesis of I/R-induced renal injury[31]. Reducing the influx of $\mathrm{Ca}^{2+}$ can, therefore, effectively prevent apoptosis. Several studies show that calcium channel antagonists have favorable impact on different cells. For example, amlodipine pretreatment can counteract angiotensin II-triggered endothelial apoptosis through the upregulation of the $\mathrm{Bcl}-2$ /Bax ratio and downregualtion of the LOX1 expression [32]. Nifedipine and amlodipine play a renoprotective role on gentamicininduced renal tubular toxicity through its antioxidant properties and suppressing apoptosis [33]. Moreover, calcium channel antagonists plus angiotensin receptor blocker protect cardiac myocytes from apoptosis mediated mitochondrial pathway [34]. It has been manifested that the beneficial impact of diltiazem on cyclosporin A treated kidney transplant recipients is not through its direct cytoprotective effect on renal tubular cells but through improving the glomerular hemodynamics, protective effect on endothelium and enhancing immunosuppression [35]. Lacidipine is a third generation vasoselective lipophylic dihydropyridine calcium channel blockade with anti-atherosclerotic [36] and anti-adhesion [11] properties. It has been previously shown that lacidipine is one of several substances with powerful antioxidative effects $[37,38]$. Lacidipine is usually used as an antihypertensive agent. Lacidipine pretreatment has also been shown to prevent cyclosporine-induced nephrotoxicity [39]. Nevertheless, whether lacidipine could be used for the treatment of AKI remained unknown. We therefore hypothesized that: (1) lacidipine prevents HKC apoptosis from I/R and (2) the mechanism underlying apoptosis attenuation is related to $\mathrm{Bcl}-2$, Bax regulation and the change of cyt $c$ level.

Apoptosis can be triggered by a variety of stressors such as inflammatory cytokines, ischemia, oxidative stress, etc. Apoptotic mechanisms are complex, with factors affecting a number of pathways. Among the multiple mediators of the complex process of apoptosis, the caspase enzyme cascade plays a central role. The caspase family is an important initiator and effector of apoptosis [24, 40]. Caspase-3 is one of the crucial enzymes among cysteine proteases that exist as inactive zymogens. The intrinsic pathway initiates apoptosis through the release of cyt $c$ into the cytosol, and results in activation of caspase-3. The activation of caspase- 3 results in the degradation and deactivation of important proteins. Caspase- 3 activation is observed during the course of apoptosis induced by triptolide in human proximal tubular cell [41]. The release of cyt $c$ from the mitochondria is regulated by various proteins including the anti-apoptotic protein, Bcl-2, and the pro-apoptotic Bax protein [42, 43].

It seems to be possible to alleviate AKI by inhibiting caspase-3- mediated cell apoptosis [23]. In the present study, caspase- 3 activity was reduced by lacidipine treatment. The extent of early apoptosis was also decreased by lacidipine treatment, as measured by flow cytometric. As shown in Fig. 3, these findings indicated that lacidipine is capable of alleviating the cytotoxicity associated with the injury. Our in vitro results correlated with the results of an in vivo study [39]. This study certified that lacidipine has a protective effect on the kidney that is independent of its blood-pressure lowering effect. We observed that apoptosis attenuation by lacidipine follows ATP depletion and recovery via the caspase- 3 mediated mechanism. As shown in Fig. 4, Bcl-2 protein levels increased and Bax protein levels decreased in the lacidipine group, corresponding with the reduction in cyt $c$ levels. Lacidipine was effective in upregulating Bcl-2 and downregulating Bax protein expression, and influencing the expression of cyt $c$. Lacidipine may exert its advantage by antioxidant properties, suppressing apoptosis mediated mitochondrial pathway, improving the glomerular hemodynamics and protective effect on endothelium. These findings support the hypothesis that lacidipine prevents apoptosis in HKCs, injured by ATP depletion and recovery, through regulation of the intrinsic apoptotic pathway. Interestingly, lacidipine decreased caspase-3 activity in a concentration-dependent manner (Fig. 1), but its effect on the expression of cyt $c$ and the Bcl-2 and Bax proteins differed. The levels of these proteins were decreased by lacidipine, but there were no differences between the $1 \mu \mathrm{M}$ and 10 $\mu \mathrm{M}$ groups (Fig. 4). Further studies are required to better understand kidney-protection mechanism of lacidipine. 


\section{Cellular Physiology Cell Physiol Biochem 2013;32:1040-1049 \begin{tabular}{ll|l} 
and Biochemistry & $\begin{array}{l}\text { DOI: 10.1159/000354504 } \\
\text { Publisned onine: October 04, } 2013\end{array}$ & $\begin{array}{l}\text { O 2013 S. Karger AG, Basel } \\
\text { www.karger.com/cpb }\end{array}$ \\
\cline { 2 - 3 }
\end{tabular} \\ Zhang et al.: Lacidipine Protects Against Renal Injury}

In summary, our data suggest that lacidipine treatment could protect HKCs against I/R injury by inhibiting protein expression of Bax and cyt $c$ and increasing the Bcl-2. Therefore, lacidipine might be a novel and potent therapeutic option for AKI.

\section{Conflict of Interest}

None declared.

\section{References}

1 Uchino S, Kellum JA, Bellomo R, Doig GS, Morimatsu H, Morgera S, Schetz M, Tan I, Bouman C, Macedo E, Gibney N, Tolwani A, Ronco C, Beginning and Ending Supportive Therapy for the Kidney Investigators: Acute renal failure in critically ill patients: A multinational, multicenter study. JAMA 2005;294:813-818.

2 Andreoli SP: Acute kidney injury in children. Pediatr Nephrol 2009;24:253-263.

- Goldstein SL: Acute kidney injury in children and its potential consequences in adulthood. Blood Purif 2012;33:131-137.

4 Maenpaa CJ, Shames BD, Van Why SK, Johnson CP, Nilakantan V: Oxidant-mediated apoptosis in proximal tubular epithelial cells following atp depletion and recovery. Free Radic Biol Med 2008;44:518-526.

5 Zhang ZX, Shek K, Wang S, Huang X, Lau A, Yin Z, Sun H, Liu W, Garcia B, Rittling S, Jevnikar AM: Osteopontin expressed in tubular epithelial cells regulates nk cell-mediated kidney ischemia reperfusion injury. J Immunol 2010;185:967-973.

6 Bellomo R, Chapman M, Finfer S, Hickling K, Myburgh J: Low-dose dopamine in patients with early renal dysfunction: A placebo-controlled randomised trial. Australian and new zealand intensive care society (anzics) clinical trials group. Lancet 2000;356:2139-2143.

7 Bagshaw SM, Delaney A, Haase M, Ghali WA, Bellomo R: Loop diuretics in the management of acute renal failure: A systematic review and meta-analysis. Crit Care Resusc 2007;9:60-68.

8 Bellomo R, Kellum JA, Ronco C: Acute kidney injury. Lancet 2012;380:756-766.

-9 Kyselovic J, Krenek P, Wibo M, Godfraind T: Effects of amlodipine and lacidipine on cardiac remodelling and renin production in salt-loaded stroke-prone hypertensive rats. Br J Pharmacol 2001;134:1516-1522.

10 Krenek P, Salomone S, Kyselovic J, Wibo M, Morel N, Godfraind T: Lacidipine prevents endothelial dysfunction in salt-loaded stroke-prone hypertensive rats. Hypertension 2001;37:1124-1128.

11 Park JK, Fiebeler A, Muller DN, Mervaala EM, Dechend R, Abou-Rebyeh F, Luft FC, Haller H: Lacidipine inhibits adhesion molecule and oxidase expression independent of blood pressure reduction in angiotensin-induced vascular injury. Hypertension 2002;39:685-689.

12 Taddei S, Virdis A, Ghiadoni L, Sudano I, Salvetti A: Effects of antihypertensive drugs on endothelial dysfunction: Clinical implications. Drugs 2002;62:265-284.

13 Ueda N, Kaushal GP, Shah SV: Apoptotic mechanisms in acute renal failure. Am J Med 2000;108:403-415.

14 Andreoli SP: Acute renal failure. Curr Opin Pediatr 2002;14:183-188.

15 Yaklin KM: Acute kidney injury: An overview of pathophysiology and treatments. Nephrol Nurs J 2011;38:13-18; quiz 19.

16 Pham NA, Robinson BH, Hedley DW: Simultaneous detection of mitochondrial respiratory chain activity and reactive oxygen in digitonin-permeabilized cells using flow cytometry. Cytometry 2000;41:245-251.

17 Balaban RS, Nemoto S, Finkel T: Mitochondria, oxidants, and aging. Cell 2005;120:483-495.

18 King MA: Antimycin a-induced killing of hl-60 cells: Apoptosis initiated from within mitochondria does not necessarily proceed via caspase 9. Cytometry A 2005;63:69-76.

19 Park WH, Han YW, Kim SH, Kim SZ: An ros generator, antimycin a, inhibits the growth of hela cells via apoptosis. J Cell Biochem 2007;102:98-109.

20 Zager RA, Johnson AC, Hanson SY: Renal tubular triglyercide accumulation following endotoxic, toxic, and ischemic injury. Kidney Int 2005;67:111-121.

21 Du J, Zhang L, Yang Y, Li W, Chen L, Ge Y, Sun C, Zhu Y, Gu L: Atp depletion-induced actin rearrangement reduces cell adhesion via p38 mapk-hsp27 signaling in renal proximal tubule cells. Cell Physiol Biochem 2010;25:501-510. 


\section{Cellular Physiology Cell Physiol Biochem 2013;32:1040-1049

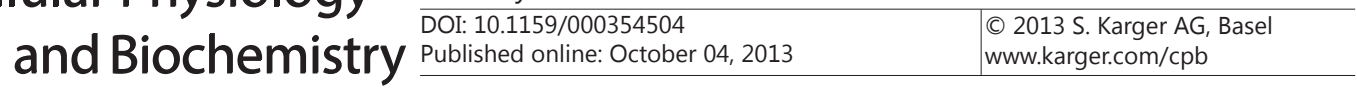

Zhang et al.: Lacidipine Protects Against Renal Injury

22 Wang J, Ouyang C, Chen X, Fu B, Lu Y, Hong Q: Effect of jak2 kinase inhibition on stat1 and stat3 activation and apoptosis of tubular epithelial cells induced by atp depletion/recovery. J Nephrol 2008;21:919-923.

-23 Saikumar P, Venkatachalam MA: Role of apoptosis in hypoxic/ischemic damage in the kidney. Semin Nephrol 2003;23:511-521.

24 Bonegio R, Lieberthal W: Role of apoptosis in the pathogenesis of acute renal failure. Curr Opin Nephrol Hypertens 2002;11:301-308.

-25 Havasi A, Borkan SC: Apoptosis and acute kidney injury. Kidney Int 2011;80:29-40.

-26 Chien CT, Chang TC, Tsai CY, Shyue SK, Lai MK: Adenovirus-mediated bcl-2 gene transfer inhibits renal ischemia/reperfusion induced tubular oxidative stress and apoptosis. Am J Transplant 2005;5:1194-1203.

27 Xue F, Isaka Y, Takahara T, Imamura R, Suzuki C, Ichimaru N, Michieli P, Takahara S: Hgf-msp chimera protects kidneys from ischemia-reperfusion injury. Biochem Biophys Res Commun 2007;363:451-456.

28 Ruchalski K, Mao H, Singh SK, Wang Y, Mosser DD, Li F, Schwartz JH, Borkan SC: Hsp72 inhibits apoptosisinducing factor release in atp-depleted renal epithelial cells. Am J Physiol Cell Physiol 2003;285:C14831493.

29 Ruchalski K, Mao H, Li Z, Wang Z, Gillers S, Wang Y, Mosser DD, Gabai V, Schwartz JH, Borkan SC: Distinct hsp70 domains mediate apoptosis-inducing factor release and nuclear accumulation. J Biol Chem 2006;281:7873-7880.

-30 Boehning D, Patterson RL, Snyder SH: Apoptosis and calcium: New roles for cytochrome c and inositol 1,4,5-trisphosphate. Cell Cycle 2004;3:252-254.

-31 Yamashita J, Kita S, Iwamoto T, Ogata M, Takaoka M, Tazawa N, Nishikawa M, Wakimoto K, Shigekawa M, Komuro I, Matsumura Y: Attenuation of ischemia/reperfusion-induced renal injury in mice deficient in $\mathrm{Na}^{+} / \mathrm{Ca}^{2+}$ exchanger. J Pharmacol Exp Ther 2003;304:284-293.

32 Bian YF, Yang HY, Yang ZM, Gao F, Zhang NN, Xiao CS: Amlodipine treatment prevents angiotensin IIinduced human umbilical vein endothelial cell apoptosis. Arch Med Res 2011;42:22-27.

33 Li J, Li QX, Xie XF, Ao Y, Tie CR, Song RJ: Differential roles of dihydropyridine calcium antagonist nifedipine, nitrendipine and amlodipine on gentamicin-induced renal tubular toxicity in rats. Eur J Pharmacol 2009;620:97-104.

34 Bahrudin U, Ikeda N, Utami SB, Maharani N, Morikawa K, Li P, Sobirin MA, Hasegawa A, Sakata S, Endo R, Rifqi S, Shirayoshi Y, Yamamoto K, Ninomiya H, Hisatome I: Simultaneous treatment with azelnidipine and olmesartan inhibits apoptosis of hl-1 cardiac myocytes expressing e334k cmybpc. Drug Res (Stuttg) DOI: 10.1055/s-0033-1347188.

35 Cheng CH, Hsieh CL, Shu KH, Chen YL, Chen HC: Effect of calcium channel antagonist diltiazem and calcium ionophore a23187 on cyclosporine a-induced apoptosis of renal tubular cells. FEBS Lett 2002;516:191196.

-36 Zanchetti A, Bond MG, Hennig M, Neiss A, Mancia G, Dal Palu C, Hansson L, Magnani B, Rahn KH, Reid JL, Rodicio J, Safar M, Eckes L, Rizzini P, European Lacidipine Study on Atherosclerosis i: Calcium antagonist lacidipine slows down progression of asymptomatic carotid atherosclerosis: Principal results of the european lacidipine study on atherosclerosis (elsa), a randomized, double-blind, long-term trial. Circulation 2002;106:2422-2427.

37 Sobal G, Menzel EJ, Sinzinger H: Calcium antagonists as inhibitors of in vitro low density lipoprotein oxidation and glycation. Biochem Pharmacol 2001;61:373-379.

38 Cominacini L, Fratta Pasini A, Garbin U, Pastorino AM, Davoli A, Nava C, Campagnola M, Rossato P, Lo Cascio V: Antioxidant activity of different dihydropyridines. Biochem Biophys Res Commun 2003;302:679-684.

-39 Kuypers DR, Neumayer HH, Fritsche L, Budde K, Rodicio JL, Vanrenterghem Y, Lacidipine Study G: Calcium channel blockade and preservation of renal graft function in cyclosporine-treated recipients: A prospective randomized placebo-controlled 2-year study. Transplantation 2004;78:1204-1211.

-40 Guo R, Wang Y, Minto AW, Quigg RJ, Cunningham PN: Acute renal failure in endotoxemia is dependent on caspase activation. J Am Soc Nephrol 2004;15:3093-3102.

41 Shu B, Duan W, Yao J, Huang J, Jiang Z, Zhang L: Caspase 3 is involved in the apoptosis induced by triptolide in hk-2 cells. Toxicol In Vitro 2009;23:598-602.

-42 Breckenridge DG, Xue D: Regulation of mitochondrial membrane permeabilization by bcl-2 family proteins and caspases. Curr Opin Cell Biol 2004;16:647-652.

43 Wei MC, Zong WX, Cheng EH, Lindsten T, Panoutsakopoulou V, Ross AJ, Roth KA, MacGregor GR, Thompson CB, Korsmeyer SJ: Proapoptotic bax and bak: A requisite gateway to mitochondrial dysfunction and death. Science 2001;292:727-730. 